\title{
Assessment of Ta'widh and Gharamah in Islamic Financing Contract and Its Applicability Potential for Construction Works Contracts
}

\author{
Noor Aishah Mohamad Hamdan ${ }^{1}$, Azila Ahmad Sarkawi ${ }^{2}$, \\ Siti Nora Haryati Abdullah Habib ${ }^{2}$, Ahmad Azam Othman ${ }^{3}$
}

\begin{abstract}
1 Department of Quantity Surveying, Faculty of Architecture, Planning and Surveying, Universiti Teknologi MARA, Perak Branch, Seri Iskandar Campus, Seri Iskandar, 32610 Perak, Malaysia, 2, Kuliyyah of Architecture and Environmental Design, International Islamic University Malaysia, Malaysia ${ }^{3}$ Ahmad Ibrahim Kuliyyah of Laws, International Islamic University Malaysia, Malaysia
\end{abstract}

noora755@uitm.edu.my, azila@iium.edu.my, ctnora@iium.edu.my, aazam@iium.edu.my Tel: $012-3207810$

\begin{abstract}
Ta'widh and gharamah are the Shariah compliant late payment charges primarily used for Islamic financial contracts. Seven identified themes were used to qualitatively compare and contrast between the Guidelines on Late Payment Charges for Islamic Banking Institutions (2012) against the provisions of interest for late interim payment from four Malaysian construction works contracts. The findings revealed similarities and differences for identification of Shariah compliance. Recommendations were made for the harmonisation of ta'widh and gharamah in the construction works contracts while ensuring its practical and legal applicability. The outcome is beneficial for Islamic organisations and Muslims involved with the construction works.
\end{abstract}

Keywords: ta'widh and gharamah, late payment, interest,construction,

eISSN: 2398-4287@ 2020. The Authors. Published for AMER ABRA CE-Bs by e-International Publishing House, Ltd., UK. This is an open access article under the CC BYNC-ND license (http://creativecommons.org/licenses/by-nc-nd/4.0). Peer-review under responsibility of AMER (Association of Malaysian Environment-Behaviour Researchers), ABRA (Association of Behavioural Researchers on Asians) and cE-Bs (Centre for Environment-Behaviour Studies), Faculty of Architecture, Planning \& Surveying, Universiti Teknologi MARA, Malaysia.

DOI: https://doi.org/10.21834/ebpj.v5i15.2504

\subsection{Introduction}

Islamic banks have incorporated the provisions of ta'widh and gharamah as a Shariah compliant mechanism in its Islamic financing contracts to combat late payment from their customers. Shariah refers to the set of rules, regulations, teachings and values governing the lives of Muslims (Abdurrahman, 2009; Mohammad Hashim, 2008). Shariah Resolution in Islamic Finance (2010) has defined ta'widh as a claim for compensation arising from the actual loss suffered by the financier due to the delay in payment of financing/debt amount by the customer. Whilst gharamah refers to the penalty charge imposed for the delay in financing/debt settlement, without the need to prove the actual loss suffered. Late payment of debt is denounced by Prophet Muhammad (pbuh) as narrated by Abu Huraira:

\section{"Procrastination (delay) in paying debts by a wealthy person is injustice".}

(Al-Bukhari, The Book of Hawalat, Chapter 1, No 1060)

Sources of indebtedness could be in the form of a loan, as part of the agreement of a contract or compensation for financial losses due to breach of contractual obligation (Nik Mohd Zaim, Ishak, \& Monika, 2017).

eISSN: 2398-4287@ 2020. The Authors. Published for AMER ABRA cE-Bs by e-International Publishing House, Ltd., UK. This is an open access article under the CC BYNC-ND license (http://creativecommons.org/licenses/by-nc-nd/4.0/). Peer-review under responsibility of AMER (Association of Malaysian Environment-Behaviour Researchers), ABRA (Association of Behavioural Researchers on Asians) and cE-Bs (Centre for Environment-Behaviour Studies), Faculty of Architecture, Planning \& Surveying, Universiti Teknologi MARA, Malaysia.

DOI: https://doi.org/10.21834/ebpj.v5i15.2504. 
In the context of construction works contract, late payment by the employer on a certified interim certificate within the period agreed in the contract legally qualifies the contractor for financial compensation in the form of interest, based on the principle of damages (Siti Suhana \& Rosli, 2010). Section 74(n) of the Malaysian Contract Acts 1950 allows for interest to be charged as an additional payment on top of the delayed principal amount. Unfortunately, Norman and Alifah (2017) had criticised the striking resemblance of riba' with the conventional legal practice of interest earnings based on damages from financial claims and money judgement. This compromises the contractual interest provision for late interim payment in terms of its compliance with the Shariah. Literally, riba' means increase, expansion, excess, addition or growth and is highly prohibited in Shariah contracts (Mohammad Hashim, 2013). In the Al-Quran, Allah says:

"O, believers! Devour not usury (riba'), doubling and redoubling its rate many time..."

(Al-Quran, 3:130)

This is alarming as many of the Islamic organisations and Muslims in Malaysia are actively involved with construction works, acting as either the developer or the contractor. In addition to riba', gharar (uncertainties) and maysir (gambling) are also highly prohibited under a Shariah compliant contract (Mohd. Ma'sum, 2006). As highlighted by Mohd Helmi \& Najahudin (2017), Shariah non-compliance do not only affect worldly affairs but also faced impediments from Allah's blessings. Although the nature between the two contracts used for comparison is different i.e Islamic financing contracts vis-a-vis conventional construction contracts, both contracts shared the same attributes on the financial losses due to the inability to utilise the fund for other financial purposes by not receiving it on time. Therefore, this paper aims to assess the potential applicability of ta'widh and gharamah with the provision of interest for late interim payment charges provided under the Malaysian construction contracts.

\subsection{Objectives of the paper}

To achieve the aim, the following objectives are outlined:

1. To identify the provision of ta'widh and gharamah from the Guidelines on Late Payment Charges for Islamic Banking Institutions (2012) against the provisions of interest for late interim payment in the Malaysian construction contracts.

2. To determine the Shariah compliant and non-compliant elements in the conventional interest provisions for late interim payment under the Malaysian construction contracts.

3. To establish the potential applicability of ta'widh and gharamah with the current interest provisions for late interim payment under the Malaysian construction contracts.

\subsection{Literature Review}

\subsection{Ta'widh and gharamah in Islamic financing contracts}

The Shariah Standards defines default in payment as a delay in the settlement of an obligation or in paying an amount due for payment, without any legitimate reason (AAOIFI, 2017). Contemporary Muslim scholars such as Mustafa Al-Zarqa, Syeikh Muhammad Sadiq AdDharir and Sheikh Abdullah Bin Mani' has agreed on the imposition of ta'widh (compensation) and gharamah (penalty) as the most suitable methods of financial remedies to be adopted for late payments in the Islamic finance industry (Ezani et al., 2014). The tenets of Islamic legal maxims allows for harms caused by financial losses due to payment defaults to be avoided and mitigated (Mohammad Akram, 2014). Thus, the amount of compensation is allowed to be taken as income. The justification of imposing gharamah together in combination with ta'widh is to increase the efficacy of late payment charge in avoiding financial defaults (Ali Muhyi al-Din, 2014).

However, additional payment above the principal amount of loan/debt tantamounts to riba' (Aznan Hassan, 2011). For the rate of compensation to be Shariah compliant, actual losses must be proven (Muhammad 'Abd al-Razzaq, 2014). Hence, Islamic scholars have emphasis on the importance on the calculation of ta'widh and gharamah which includes the time period to impose them for the late payment charges to be legitimate under the (Ezani et al., 2013; Norwajia Umi, Mat Noor, \& Salmy Edawati, 2014). Whilst the direct purpose of ta'widh is to compensate for actual losses suffered due to the financial default, the imposition of gharamah as a financial penalty requires careful deliberation to instil discipline amongst debtor in making timely payment (Aishath, Nur Adibah, Ruqayyah, Siti Nadzirah, \& Zakariya, 2019; Ezani et al., 2014; Norwajia Umi et al., 2014). Financial penalty seeks to deter the public from committing similar offences (Mohamed Azam \& Ahmad Badri, 2016). However, careful considerations must be given in the computation of these charges to avoid riba'.

In Malaysia, the regulatory framework for the imposition of ta'widh and gharamah for the Islamic financing contracts is according to the guidelines provided by the Shariah Advisory Council (SAC) under the purview of the Malaysian Central Bank. Ta'widh and gharamah could be incorporated into various Islamic financial contracts but not exhaustive to; Murabahah, Salam, Istisna', Musyarakah, Mudharabah and ljarah contracts. It is worth to highlight that Istisna' (manufacturing) contract is the closest form of Islamic financial contract that resembles the features of a conventional construction contract. Istisna' refers to a contract which a seller sells to a purchaser an asset which is yet to be constructed, built or manufactured according to agreed specifications and delivered on an agreed specified future date at an agreed pre-determined price. The payments for an istisna' asset can be in the form of spot, progressive or deferred payments (Bank Negara Malaysia, 2015). However, the claim of ta'widh under the Istisna' contract is directed to the actual cost incurred in the event th e purchaser decides to cancel the order after a binding promise to enter the contract was made. To date, financial penalties often discussed in Istisna' contract only focuses on the delay of the seller in delivering the completed assets (Bank Negara Malaysia, 2015; Muhammad Al-Amine, 2001). Further studies related to ta'widh and gharamah specifically for Istisna' contracts remain 
scarce.

\subsection{Compensation and penalty for late interim payment in Malaysian construction works contracts}

Late interim payment for construction works contract is described as the failure of the employer to disburse full payment of the certified amount in the interim payment certificate to the contractor within the period agreed in the contract (Siti Suhana, Nuremma, \& Roselan, 2017). A study conducted by Hamzah et al. (2015) revealed the top five most frequent causes for late payment are; delay in certification, paymaster's poor financial management, local culture/attitude, paymaster's failure to implement good governance in business and underpayment of the certified amount. Interestingly, the issue of local culture/attitude is reiterated by Jalilah, Azwina, Choy, Mohamed Ishak, \& Siti Marshita (2015) by suggesting that delay in payment attitudes of the employer is equated to negligence. Late interim payment is regarded as a prominent factor contributing to the contractor's financial instability which ultimately affects the progress of the construction works (Akisinku, Emmanuel Olusegun Ajayi, 2016).

The contractor can exercise their contractual rights to receive financial compensation for late interim payment through the provision of interest in the contract. Interest is charged on the principal amount due to restore the financial position of the contractor had the payment been made on time. Under the conventional practise, delayed payment is related to the loss of monetary value at market rate (SQA Builders Sdn. Bhd. v Luxor YRM Sd. Bhd. \& Anor. [2018] 1 CIDB-CLR 319). Hence, the relevant of using a selected bank's base lending rates as a reference for the interest to be charged. The rate is calculated from the date of default until payment has been made in full (Siti Suhana \& Rosli, 2010).

Presently, there is no statute in Malaysia which makes it compulsory to include interest for late interim payment as a provision in the formation of a construction contract. The contractual effects of this lacuna are, the provision might be incomplete, exempted or amended. These effects would exclude or restrict one party's liability or rights which may arise should that party be in breach of the contract (Farhah \& Sakina, 2018). In the absence of such provision in the contract, a contractor who intends to seek the recovery of interest for late interim payment could refer the issue under the purview of Section 25(0) of CIPAA 2012. This statute empowers the Adjudicator to award interest on late interim payment. However, there is lack of concerns for these contractual and legal provisions related to interest for late interim payment to be assessed in terms of its compliance to the Shariah (Noor Aishah, Azila \& Siti Nora Haryati, 2019).

\subsection{Methodology}

This paper employs a qualitative approach to comparative analysis. The method is best employed when a specific phenomenon is compared between different entities to achieve better understanding, allows for similarities and differences to be observed as well as identified thus allowing further evaluation on how each entity responds to the phenomenon (Azarian, 2011; Pickvance, 2001). The themes for comparison for this paper were derived from a content analysis of selected law cases compiled in the Construction Industry Development Board (CIDB) Construction Law Reports from the year 2015 to 2018. This has produced seven relevant themes pertinent to the provision of contractual interest for late interim payment in the Malaysian construction contracts,namely; rate, formula, assessment, limitation for quantum, calculation, duration and classification of defaulters. These themes were subsequently verified with two construction law experts and one construction practitioner having vast experience dealing with contractual interest for late interim payment for construction works. This is to ensure a holistic view related to practical and legal issues on the provision were addressed.

Four most common Malaysian construction contracts from the private and public sectors (Sundra \& Harban Singh, 2012) were selected as the samples for contractual provisions for late interim payment, which are:

1. The Agreements and Conditions of PAM Contract 2018 (with/without quantities) issued by Pertubuhan Arkitek Malaysia (PAM).

2. IEM Form of Contract for Civil Engineering Works (Second Edition, July 2011) issued by the Institution of Engineers Malaysia (IEM).

3. CIDB Standard Form of Contract for Building Works (2000 Edition) issued by the Construction Industry Development Board of (CIDB).

4. P.W.D Standard Form of Contract 203A (Rev. 1/2010) issued by the Public Works Department (PWD) under the Malaysian Ministry of Public Works.

The sample for the mechanism of ta'widh and gharamah in financing contracts is The Guidelines on Late Payment Charges for Islamic Banking Institutions (2012) published by the Shariah Advisory Council (SAC) of the Central Bank of Malaysia.

\subsection{Comparative Analysis}

Table 1 provides a comparison of the concepts and practices extracted from the selected samples. From this, two non-compliances (rate and classification of defaulters), one part-compliant (duration) and four compliances (formula, limitation to quantum, duration and assessment) to the Shariah were identified and further discussed in the following sub-sections (4.2-4.8).

Table 1. Comparison of Ta'widh and Gharamah in Islamic Financing Contracts against the Contractual Construction Provision on Interest for Late Interim Payment

\begin{tabular}{|c|c|c|c|c|c|c|}
\hline \multirow{2}{*}{ Themes } & \multirow{2}{*}{$\begin{array}{l}\text { Late Payment Charges under the } \\
\text { Guidelines for Late Payment Charges for } \\
\text { Islamic Banking Institutions (2012) }\end{array}$} & \multicolumn{5}{|c|}{ Interest provision for late interim payment in the Malaysian Construction Works Contracts / Clause } \\
\hline & & $\begin{array}{l}\text { PAM Contract } \\
2018 \text { (with/without } \\
\text { quantities) / } \\
\text { Clause } 30.17\end{array}$ & $\begin{array}{l}\text { IEM Form of } \\
\text { Contract for Civil } \\
\text { Engineering Works } \\
\text { (Second Ed., July } \\
\text { 2011) (corrigendum }\end{array}$ & $\begin{array}{l}\text { CIDB Standard } \\
\text { Form of Contract } \\
\text { for Building Works } \\
\text { (2000 Edition) / } \\
\text { Clause } 42.9\end{array}$ & $\begin{array}{l}\text { P.W.D } \\
\text { Standard Form } \\
\text { of Contract } \\
203 A \text { (Rev. } \\
\text { 1/2010) / not } \\
\text { available }\end{array}$ & $\begin{array}{l}\text { Compliance } \\
\text { assessment } \\
\text { to the } \\
\text { Shariah }\end{array}$ \\
\hline
\end{tabular}




\begin{tabular}{|c|c|c|c|c|c|c|}
\hline & & \\
\hline & & & $\begin{array}{l}\text { No. 1)/ Clause } \\
58.3\end{array}$ & & & \\
\hline Rate & $\begin{array}{l}\text { - The rate of ta'widh is based on actual } \\
\text { losses }(1 \%) \\
\text { - May be of ta'widh alone or } \\
\text { combination with gharamah } \\
\text { - The rate for gharamah }(\mathrm{G}) \text { is the } \\
\text { difference between the maximum } \\
\text { combined rate }(\mathrm{C}) \text { with ta'widh }(\mathrm{T})\end{array}$ & Maybank BLR+1\% & $\begin{array}{l}6 \% \text { (unless } \\
\text { otherwise agreed) }\end{array}$ & $\begin{array}{l}\text { Maybank BLR+2\% } \\
\text { (unless otherwise } \\
\text { agreed) }\end{array}$ & Not available & Non-compliant \\
\hline Formula & $\begin{array}{l}\text { Simple interest. Strictly non- } \\
\text { compounding }\end{array}$ & Simple interest & Simple interest & Simple interest & Not available & Compliant \\
\hline Assessment & $\begin{array}{l}\text { - Ta'widh as contractual rights for } \\
\text { compensation and can be taken as } \\
\text { income } \\
\text { - May impose gharamah as penalty } \\
\text { and deterrent mechanism but cannot } \\
\text { be taken as income } \\
\text { - Gharamah must be kept in a } \\
\text { separate account and channelled to } \\
\text { charitable organisations }\end{array}$ & $\begin{array}{l}\text { Contractual rights } \\
\text { for compensation } \\
\text { and can be taken as } \\
\text { income }\end{array}$ & $\begin{array}{l}\text { Contractual rights } \\
\text { for compensation } \\
\text { and can be taken } \\
\text { as income }\end{array}$ & $\begin{array}{l}\text { Contractual rights } \\
\text { for compensation } \\
\text { and can be taken } \\
\text { as income }\end{array}$ & Not available & Compliant \\
\hline $\begin{array}{l}\text { Limitation for } \\
\text { quantum }\end{array}$ & $\begin{array}{l}\text { - Not more than the prescribed rate of } \\
\text { ta'widh by the SAC } \\
\text { - The maximum combined rate is } \\
\text { capped at a prescribed rate; Average } \\
\text { Financing Rate (AFR) determined at } \\
\text { the date of default } \\
\text { - Maximum combined rate not more } \\
\text { than the conventional interest } \\
\text { - Maximum combined rate not } \\
\text { exceeding } 100 \% \text { of the outstanding } \\
\text { principal amount for combined } \\
\text { charges }\end{array}$ & $\begin{array}{l}\text { Not more than the } \\
\text { stipulated } \\
\text { contractual rate }\end{array}$ & $\begin{array}{l}\text { Not more than the } \\
\text { stipulated } \\
\text { contractual rate }\end{array}$ & $\begin{array}{l}\text { Not more than the } \\
\text { stipulated } \\
\text { contractual rate }\end{array}$ & Not available & Compliant \\
\hline Calculation & $\begin{array}{l}\text { - Per annum basis for ta'widh } \\
\text { - Per monthly basis for maximum } \\
\text { combined rate capped at AFR }\end{array}$ & Per annum basis & $\begin{array}{l}\text { Per annum basis } \\
\text { unless otherwise } \\
\text { agreed }\end{array}$ & $\begin{array}{l}\text { Per annum basis } \\
\text { unless otherwise } \\
\text { agreed }\end{array}$ & Not available & Compliant \\
\hline Duration & Until settlement of payment & $\begin{array}{l}\text { Until settlement of } \\
\text { payment }\end{array}$ & $\begin{array}{l}\text { Accrue from the } \\
\text { date of default }\end{array}$ & $\begin{array}{l}\text { Until settlement of } \\
\text { payment }\end{array}$ & Not available & Part compliant \\
\hline $\begin{array}{l}\text { Classification } \\
\text { of defaulter }\end{array}$ & Only imposed on negligent defaulters & Non stated & Non stated & Non stated & Not available & Non-compliant \\
\hline
\end{tabular}

${ }^{*} \mathrm{BLR}=$ Base Lending Rates

\subsection{Findings and Discussions}

\subsection{Rate}

The rate for ta'widh in the guidelines is prescribed by the SAC based on the actual financial losses deemed suffered by the Islamic Banks Institutions (IBI). The guidelines also allow for a determination of rate for gharamah as a penalty to be charged with ta'widh within certain limitations to the combined rate (Figure 1). In comparison, PAM 2018 and CIDB 2000 contracts had specified the rate of interest to be contingent upon a local bank's commercial interest rate which is the base lending rate (BLR). In addition, the absence of a provision to deal with financial losses due to late interim payment in P.W.D 203A contract could amount to gharar (uncertainties) in the contract. Gharar could render the contract void (Fazli Dayan \& Mian Muhammad, 2016). Penalty to late interim payment is also not included as part of the provision in the construction works contracts.

\subsection{Formula}

The guidelines explicitly highlight on the prohibition of the late payment charges to be compounded. Compounding of late payment charges is a clear indication of riba' (Al-Quran, 3:130) and is highly prohibited. Similarly, the provision for simple interest in the construction works contracts as the formula for interest charges is also expressly stated in all the construction works contracts.

\subsection{Assessment}

Both ta'widh and the contractual interest for late interim payment is treated as compensation for the contractor.Under the Shariah, it is permissible for the proceeds from the financial compensation, which is the practise of the construction works contracts as well. Due to the purpose of gharamah as a penalty, the Shariah prohibits the amount from gharamah to be taken by the IBI as income because it 
would be considered as riba'. Instead, the income from gharamah must be separately managed and channelled to charitable organisations.

\subsection{Limitation for quantum}

Ta'widh shall not be charged more than the prescribed rate. For the combined rate, three types of capping apply (Table 1). Special attention is given to the maximum combined rate (C) capped at the IBI's respective Average Financing Rate (AFR) (Figure 1). AFR is the organisational profit rate and will differ from each IBI and financing contracts to another. Because the rate of AFR fluctuates, it needs to be computed at the point of default and revised monthly until the payment is made.

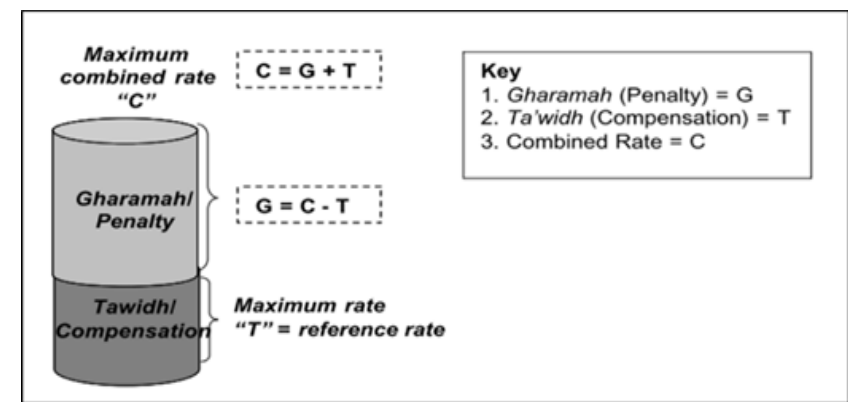

Fig. 1: Late payment Charge Structure (Guidelines on Late Payment Charges for Islamic Banking Institutions, 2012)

Consistent with the practice of ta'widh, the charge of interest for late interim payment in the construction works contract is also limited to the specified rate as stated in the contract. Due to the absence of penalty in the provision for conventional interest, the maximum cumulative charge for $(\mathrm{C})$ does not apply as the rate is meant to curb an excessive rate of gharamah.

\subsection{Calculation}

It is typical for charges for late payment, either conventional or Islamic to be calculated per annum basis unless otherwise agreed in the contract. The charges could also be calculated on a monthly or daily basis depending on the types of rates used. The formula for the calculation is:

$$
\text { Principal amount of debt } x \text { rate of interest@rate of late payment charge x (Days of delay) }
$$

This practise is consistent in both the guidelines and the construction works contracts.

\subsection{Duration}

The duration for late payment charge is illustrated clearly in the guidelines to be from the point of default until the maturity date or until the facility is recalled. The duration for the charging of interest for late interim payment is also expressly stated in the construction works contracts to be from the point of default until payment is made, except for the IEM CE 2011 contract. The said contract only highlights the point where the contractor starts to be entitled to charge the interest but not the end of the charging period. This provision is considered incomplete and can lead to gharar.

\subsection{Classification of defaulter}

Islam pays high attention to those having genuine financial difficulties in paying their debt. In the Al-Quran, Allah says:

"But if the debtor is in a hard time, grant him a delay until he can pay his debt........"

(Al-Quran, 2:280)

Therefore, late payment charges under the guidelines are only imposed on negligent defaulters i.e reasonable circumstances for delaying payment. In the construction works contract, no such classification is given for the employer who intentionally or unintentionally delays the interim payment. Under the Malaysian law, the recovery of debt and interest due to late interim payment is targeted at solvent (having assets to settle debt) or insolvent debtor (not enough assets to settle debt) (Siti Suhana \& Rosli, 2010).

Based on the discussions of the findings, it can be seen that both Shariah compliant practices of ta'widh and gharamah in the

Islamic financing contracts and the Malaysian construction works contracts have more similarities (5) than differences (3). The similarities are found in the formula, assessment, limitation of quantum, calculation and duration. While the differences are found in the determination of rate, imposition of penalty and classification of defaulters as illustrated in Figure 2. 


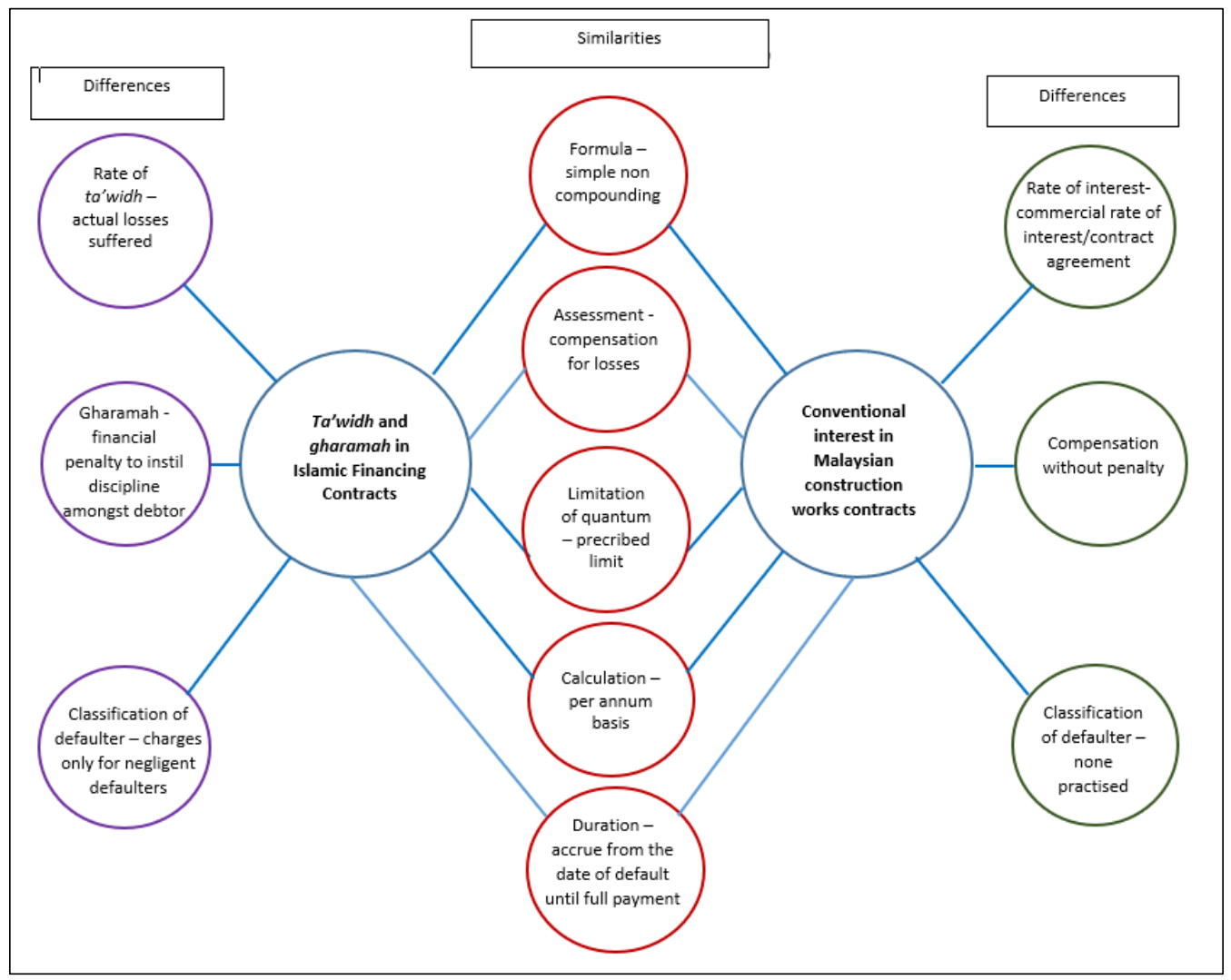

Fig. 2: Similarities and Contrasting Features of Ta'widh and Gharamah in Islamic Financing Contracts with the Contractual Construction Provision of Interest for Late Interim Payment

\subsection{Recommendations}

\subsection{Determination of rate for actual losses}

The determination of actual loss is the most pivotal element of ta'widh. The contractor should prepare a list of items to be evaluated for actual losses in the occurrence of late interim payment before signing the contract. This list must be mutually agreed by the employer as well. However, if the reference to commercial interest is verified as the actual loss, BLR should be changed to BFR (Base Financing Rate) as the equivalent rate approved by the Shariah.

\subsection{Introduction of penalty (gharamah)}

i. Penalty is allowed under Section 75 of the Malaysian Contracts Acts 1950. The imposition of penalty is targeted for negligent employers who intentionally delays payment.

ii. There needs to be a balanced approach crafted for the construction works on deciding the suitable rate for penalty to achieve its objectives.

iii. Instead of charitable organisations, the amount of the penalty could be channelled to the Construction Industry Development Board (CIDB) as the overseeing organisation for construction activities in Malaysia. The fund could be utilised for the development of construction personnel through CIDB training programmes and modules.

\subsection{Classification of defaulters}

The contractor should be prudent in exercising his rights to imposed late payment charges. A method to classify the employer as negligent or not in his obligation to make timely payment need to be formulated. An employer who is genuine in facing financial difficulties should be able to provide pieces of evidence for considerations.

\subsection{Conclusions}

Findings from the comparison indicated more similarities than differences between the contractual provision of interest for late interim payment with the guidelines of ta'widh and gharamah in the Islamic financing contracts. This shows that ta'widh and gharamah have high potentials to be applied in the Malaysian construction contracts. The outcome of this paper is hoped to benefitted Islamic organisations and Muslims involved in the construction works in searching for a Shariah compliant mechanism to impose charges on 
late interim payment. Further research should be done to produce the details based on the recommendations for harmonisation between these two practices.

\section{Paper Contribution to Related Field of Study}

This paper has uncover the potential of adapting the principles and practices of ta'widh and gharamah to produce a Shariah compliant late payment charges to be harmonised with the conventional construction contractual provisions in the event of late interim payment from the Employer towards the contractor.

\section{References}

AAOIFI. Shari'ah Standards (2017). Kingdom of Bahrain.

Aishath, M., Nur Adibah, Z., Ruqayyah, A., Siti Nadzirah, I., \& Zakariya, M. (2019). APPLICATION OF TA ' WIDH AND GHARAMAH IN ISLAMIC BANKING IN MALAYSIA. Journal of Muamalat and Islamic Finance Research, 16(1), 1-16.

Akisinku, Emmanuel Olusegun Ajayi, O. M. (2016). Effects of Delayed Payment of Contractors on COnstruction project Delivery in Nigeria. Cobra 2016 Rics Cobra 2016, (September), 2015-2016.

Al-Quran. (n.d.). Al-Quran. (Sheikh Abdullah Basmeih, Trans.). Department of Islamic Development Malaysia.

Ali Muhyi al-Din, al-Q. D. (2014). Masalah Hutang Tertunggak dan Cara Mengatasinya di Bank Islam: Kajian Syariah Terhadap Denda Kelewatan dan Penyelesaian. In Mohd. Zain Abd. Rahman (Ed.), Ta'wid, Suyulah \& Ibra' Dalam Sistem kewangan Islam (Second, pp. 173-272). Kuala Lumpur: IBFIM.

Aznan Hassan. (2011). Fundamentals of Shari'ah in Islamic Finance. Kuala Lumpur, Malaysia: IBFIM.

Bank Negara Malaysia. (2015). Istisna'. Kuala Lumpur, Malaysia.

Ezani, Y., Mohamed Azam, M. A., Asmak, H., Mohd Dani, M., Mohammad Mahyuddin, K., \& Mohd Solahuddin, S. (2014). A Revisit to the Practice of Late Payment Charges by Islamic Banks in Malaysia. Jurnal Pengurusan, 42(February 2016), 185-190. https://doi.org/10.17576/pengurusan-2014-42-15

Ezani, Y., Mohamed Azam, M. A., Asmak, H., Mohd Dani, M., Mohd Solahuddin, S., \& Nur Hidayah, M. Y. (2013). Late Payment Charge in Islamic Bank. In The 5th International Conference on FInancial Criminology (pp. 382-387)

Farhah, A., \& Sakina, S. A. Y. (2018). A QoL2018lstanbul Empowering Malaysian Consumers through Legislation : Does 'small print ' in contract influence consumer behaviour and affect the quality of life ? Environment-Behaviour Proceedings Journal, 3(9), 97-102.

Fazli Dayan, \& Mian Muhammad, S. (2016). The Concept of Uncertainty in Islamic law : Its Reasons and Related Terms. Journal of Basic and Applied Scientific Research, 6(12), 21-34.

Hamzah, A. R., Chen, W., Faizul Azli, M. R., Nurul Safwah, M. Y., \& Mohd. Suhaimi, M. D. (2015). Delay and Payment Issues in Construction Projects. Kuala Lumpur: Um Press.

Jalilah, M. A., Azwina, A. M., Choy, C. Y., Mohamed Ishak, A. H., \& Siti Marshita, M. (2015). Is There any Accurate Solutions : Late Payment , Under Payment and a Non Payment Issues in the he Construction Industry. Australian Journal of Basic and Applied Sciences, 9(37), 97-103.

Mohamed Azam, M. A., \& Ahmad Badri, A. (2016). The Application Of Shariah Principles of Ta'zīr in Malaysian Common Law : A Maqāsid -based Proposal. Islam and Civilisational Renewal, 7(1).

Mohammad Akram, L. (2014). Prinsip Ganti Rugi dan Denda Terhadap Penangguhan Pembayaran Hutang Dalam Kewangan Islam. In Mohd. Zain Abd. Rahman (Ed.), Ta'wid, Suyulah \& Ibra' Dalam Sistem kewangan Islam (Second, pp. 121-171). Kuala Lumpur: IBFIM.

Mohammad Hashim, K. (2013). Permissibility and Prohibitions in Islamic Transactions and Contracts. In Mohammad Hashim Kamali and Sheila Ainon Yusoff (Ed.), Islamic Transactions and Finance: Principles and Developments (pp. 1-28). Kuala Lumpur: The Malaysian Current Law Journal and International Institute of Advanced Islamic Studies

Mohd. Ma'sum, B. (2006). Shar'iah Standard of Business Contract. Kuala Lumpur, Malaysia: A.S Nordeen.

Mohd Helmi, A., \& Najahudin, L. (2017). The Development of Shariah Risk Management Model (SRM-i) for the Use of Shariah Compliance Organizations. EnvironmentBehaviour Proceedings Journal, 5(SI1), 79-84. https://doi.org/10.21834/ebpj.v5iSI1.2301

Muhammad 'Abd al-Razzaq, al-S. I. al-T. (2014). Ganti Rugi Kerana Kemudaratan Serta Denda Lewat Membayar Hutang dan Perlaksanaannya di Institusi Kewangan Islam di Kuwait. In Mohd. Zain Abd. Rahman (Ed.), Ta'wid, Suyulah \& Ibra' Dalam Sistem kewangan Islam (Second, pp. 81-120). Kuala Lumpur: IBFIM.

Muhammad Al-Amine, M. A.-B. (2001). Istisna' (Manufacturing Contract) in Islamic Banking and Finance. Kuala Lumpur, Malaysia: A.S Nordeen.

Noor Aishah, M. H., Azila, A. S., \& Siti Nora Haryati, A. H. (2019). ESTABLISHMENT OF SHARIAH PRINCIPLES ON INTEREST FOR LATE INTERIM PAYMENT FOR. In International Conference on Islamic Law, Economy \& Finance (pp. 351-361). Johor Bahru, Johor: KPIJ Press.

Norwajia Umi, I., Mat Noor, M. Z., \& Salmy Edawati, Y. (2014). Kaedah Penyelesaian Kemungkiran Kontrak ( Default Payment ) dalam Islam : Sorotan Literatur Islāmmiyyāt, 36(1), 41-48. https://doi.org/http://dx.doi.org/10.1108/17506200710779521 
Noushad Ali Naseem, A. A. (2006). "A Construction Industry Payment and Adjudication Act": Reducing Payment-Default and Increasing Dispute Resolution Efficiency in Construction. Master Builders, 3(1), 4-14.

Siti Suhana, J., Nuremma, M., \& Roselan, N. (2017). A Framework for Combating Payment-Related Issues (Pri) in the Malaysian Construction Industry. Journal of Built Environment Technology and Engineering, 2. Retrieved from http://www.jbete.com/wp-content/uploads/2017/05/JBETE2_74.pdf

Siti Suhana, J., \& Rosli, A. R. (2010). Contractor's Right Of Action For Late Or Non-Payment By The Employer. Journal of Surveying, Construction \& Property, 1(1), 6595.

SQA Builders Sdn. Bhd. v Luxor YRM Sd. Bhd. \& Anor. [2018] 1 CIDB-CLR 319 